\title{
Dismantling the Prison-House of Colonial History in a Selection of Michelle Cliff's Texts
}

\author{
Abid Larbi Labidi \\ Department of English, College of Arts, King Saud University, Riyadh, Saudi Arabia \\ E-mail: alabidi@ksu.edu.sa
}

Doi:10.7575/aiac.alls.v.7n.5p.64

URL: http://dx.doi.org/10.7575/aiac.alls.v.7n.5p.64
Received: 11/05/2016

Accepted: 18/07/2016

\begin{abstract}
Most, if not all, writings by Jamaican writer Michelle Cliff are connected by a subterranean desire to re-write AfroCaribbean history from new untold perspectives in reaction to the immense loss and/or distortions that marked the region's history for entire centuries. In this paper, I meticulously read four of Cliff's texts--Abeng (1984), its sequel No Telephone to Heaven (1987), Claiming an Identity They Taught Me to Despise (1980) and The Land of Look Behind (1985)--to look at how Cliff retrieves her black ancestors' submerged history and erased past. I particularly explore the methods Cliff deploys to re-center a history deliberately erased/or distorted by what she ironically calls "the official version" (Free Enterprise, 1994, p. 138) in allusion to the Eurocentric narratives about the twin imperial projects of slavery and colonialism. Finally, I investigate the wealth of possibilities offered by fiction, unrecorded memory, oral story-telling and imagination to out-tell Eurocentric historiography and re-write Afro-Caribbean history from the victims' perspective: slaves, colonial subjects, marginalized female figures, black Diasporic characters, etc.
\end{abstract}

Keywords: Michelle Cliff, "official” history, history re-writing, memory, fiction

\section{Introduction}

It would not be tricky at all to bear out that history deeply permeates almost every single work by Jamaican female writer Michelle Cliff. Quite obviously, Cliff's entire oeuvre reverberates with distant ancestral past, African roots/routes, slavery memory, colonial traumas and an array of related flashbacks and recollections. Rody remarks that no other contemporary Caribbean writer "has engaged more overtly in the enterprise of rewriting history than Michelle Cliff" (2001, p. 151). Indeed, Cliff's texts interrelate in their memory-bound nature and tireless search for voices and testimonies from the remote Afro-Caribbean past. More often than not, Cliff's characters disclose a subterranean desire to dis/cover personal, familial, collective or communal histories and pasts. The major 'sites' of Cliff's history excavation relate to the following: the loss of the African homeland, the inflictions of the Middle Passage and plantation life, colonial encounters, the African tradition and African-Caribbean cultural bonds.

Another recurring aspect of Cliff's narratives is her characters' constant search for roots, self-definition and identity reclaiming. They often seek to reclaim "shards' of their ancestral memory to "untangle" the "filaments of [their] history," as one of Cliff's characters admits in her essay collection Claiming an Identity They Taught Me to Despise (1980, p. 8). The same speaker confesses an "attract[ion] to places where things are buried" (p. 95) and a need to "build" "images of knowledge/of remains/of burying grounds" (p. 40). Regaining the lost or silenced past requires the excavation of forgotten "places," "remains" and "grounds" the retrieval of which entails revisiting, literally and metaphorically, the diverse "places" the ancestors had either involuntarily left behind or unpredictably embarked on: the African homeland, the Atlantic Ocean, Caribbean sugar plantations, the Americas and the many disjoined loci of the African Diaspora. The word "attraction" tells about the speaker's attachment to what has been lost but not forgotten, while "buried" and "burying" articulate the extent of concealment and/or loss 'inflicted' on the speaker's history, hence the need (also duty) for reclamation and repossession.

\section{Cliff: History Retrieval as Duty}

This above-mentioned need for history reclamation takes the form of responsibility and duty for Cliff and is central to her project of history re-writing and memory regaining as she straightforwardly tells her readers in her book The Land of Look Behind (1985):

To write as a complete Caribbean woman, or man for that matter, demands of us retracing the African part of ourselves, reclaiming as our own, and as our subject, a history sunk under the sea, or scattered as potash in the cane-fields, or gone to bush, or trapped in a class system notable for its rigidity and absolute dependence on color stratification. On a past bleached from our minds. It means finding the art forms of our ancestors and speaking the patois forbidden to us. It means also realizing our knowledge will always be wanting.-It means also, I think, mixing in the art forms taught us by the oppressor, undermining his language and co-opting his style, and turning it to our purpose. (p. 
The retrieval of lost or unrecorded memory is a duty Cliff undertakes as a Postcolonial Caribbean writer. Cliff proposes that the regaining of her people's history does not simply concern her as an individual writer, but must also be the target of all Afro-Caribbean writers. Indeed, "retracing" "scattered" memory and "reclaiming" a "history" "sunk under the sea" are not a matter of choice, but rather a responsibility for the Caribbean writer to regain his/her nation's erased history. While the phrase "demands of us" suggests the sense of responsibility Cliff stresses, the accumulation of such adjectives as "sunk," "scattered," "gone," "trapped," "bleached" and "forbidden" clearly point to the huge loss that marked the history of the Afro-Caribbean world. The historical moments Cliff re-centers are: the African past ("the African part of ourselves"), the Middle Passage ("a history sunk under the sea"), plantation life (indicated by "canefields"), colonialism (suggested by "oppressor") and the racially-divided contemporary Caribbean society ("a class system notable for its rigidity and absolute dependence on color stratification").

According to Cliff, the retrieval of the untold past is necessary to counter a long history of Caribbean silence and marginalization. Indeed, re/covering memory helps "undermine" the erasure inherent in the oppressor's language and forms of mis/representation: "the forms taught us by the oppressor." The words "finding," "speaking," "mixing," "undermining," and "turning" allude to the capacity of memory to resist prejudiced constructions of history and regain the submerged legacy: "a history sunk under the sea" and "a past bleached from our minds." The verb "bleached" is indicative of the immense erasure that wraps the speaker's history and past.

Erasure, Cliff insists, is an essential part and parcel of Eurocentric history and narratives about the Caribbean world since its 'discovery' by imperialist Europe. Hence, Cliff's denouncing of the distortions and erasure inherent in "official history" becomes a leitmotif of sorts that recurs throughout most of her writings. In an interview with Opal Palmer Adisa entitled "Journey into Speech-A Writer Between Two Worlds" (1994), Cliff defines the major goal of writing her book Free Enterprise in the following terms: "One of the things I am trying to do in this book is to adjust the lens, to re-vision history" (p. 280) Cliff also tells us the following regarding the central mission of her project as a Caribbean Postcolonial writer: "to correct received versions of history" (p. 280). Cliff's reaction to the gaps and distortions characteristic of Eurocentric narratives can be studied through this extract from her novel Free Enterprise:

I do not want fame, truly, or ownership of history, for that matter, but the official version is a cheat. But then, what's to be done? The winner names the age. Renaissance, Enlightenment, Age of Reason. But then again, even when we are the winners--not of ages, my dear, of certain moments-our victories are not recorded, not really. [...] The official version is for public consumption--in both senses of the word. (1994, pp. 137-138)

In this extract, Cliff addresses the way her people's history is either distorted or erased altogether ("not recorded"). The erasure and misrepresentation characteristic of the "official version" are referred to by the following: "ownership of history," "cheat," and "The winner names the age." According to Cliff, the writing of history is not governed by what happened in reality, but is rather shaped by the interests of those who wield power and write history. Cliff's use of such words as "winner," "winners" and "victories" foregrounds the power relations which underlie the writing of history. Even the seemingly 'innocent' labelling of historical periods such as "The Renaissance," "The Age of Reason" and "The Enlightenment" is dictated by ideological blurring and "cheating." The immense erasure of the history of slave resistance ("our victories are not recorded") is but one case in point of the manipulation that deeply coloured the Eurocentric writing of slavery history.

\section{When Literature Out-Tells History}

It is interesting to note that Cliff heavily relies on the fictional text (despite its imaginary nature) to challenge the essentialist manipulations of Caribbean history and re-write her people's unknown past from new untold perspectives. The following passage from Abeng (1984) can serve me well to consolidate this argument:

[O]f all the slave societies in the New World, Jamaica was considered among the most brutal. They did not know that the death rate of Africans in Jamaica under slavery exceeded the rate of birth, and that the growth of the slave population from 1,500 in 1655 to 311,070 in 1834 , the year of freedom, was due only to the importation of more people, more slaves. They did not know that some slaves worked with their faces locked in masks of tin, so they would not eat the sugar cane as they cut. (pp. 18-19)

The above extract uncovers aspects of slavery's moral destructiveness and physical cruelties. The flow of memory is so intense that the fictional text becomes a historical account of sorts whereby slaves' weightlessness and the indignities of slavery are lucidly divulged. This extract provides an instance of how Cliff's narrative functions similarly to a historical text proper. The insertion of precise dates ("1655" and "1834"), statistics ("1,500" and " 311,070 ") and historical events ("the death rate of Africans in Jamaica") within the fictional text foregrounds the peculiar perspective from which Abeng is written. Cliff's peculiar perspective shifts the focus from "those who make History" to "those who suffer History" (Sarvan and Marhama, 1991, p. 40) and dismantles the long-held assumption that only history has a claim for truth and credibility

As a matter of fact, Cliff's novels Abeng and No Telephone to Heaven blur the austere canonical boundaries separating history from fiction. Instead, Cliff's narratives engage in what might be called a "historicising of fiction," a process whereby the literary text proves capable of retrieving what had been lost and/or distorted in "official" history about the Caribbean. Thus, Cliff adopts a subtle priority reversal whereby the imaginative text out-tells "official" historical records about slavery, colonialism and an array of black-white encounters. Cliff's belief in the need to put History and Fiction side by side is clearly voiced in her article "History as Fiction, Fiction as History": 
It is through fiction that some of us rescue the American Past. [...] Why not use our historical imaginations, envisioning the armed and organized network as extending throughout the Western Hemisphere? Wherever the institution of slavery thrived. [...] As artists [...] it is our job to imagine the unimaginable. The interior of the slave ship, for example. The rush to suicide of the cargo, for example. But also resisters, female and male. Those who organized and armed themselves and fought back. (1994, pp. 199-200)

Cliff dismantles the rigid divide between History and Fiction and weds both disciplines as equally capable of "rescuing" the past by telling it from the victim's perspective. Cliff's argument echoes what Caryl Phillips calls "the irreducibility of history to a single story" (A New World Order, 2002, p. 178). The above quotation by Cliff also shows the extremely thin layer separating (or rather connecting) Cliff's imaginative narrative from the historical text per se. Associating imagination with factual history ("The interior of the slave ship," "the rush to suicide of the cargo" and "Those who organized and armed themselves") is a necessary undertaking if the lost history of slavery is to be restored and put back in place again. Cliff's reaction to the essentialist rigid division between literature and history is strongly voiced as follows:

I can't stand the idea of the novel here, the history there, the biography there. I can't see why these things can't be mixed. We have to bring our imagination to our history, because much has been lost. What I wanted to do in Free Enterprise is to show people, wherever we come from, whatever our backgrounds, what it has done to us not to know this history. (qtd. in Shea, 1994, p. 33).

This overlap between imagination and factual history relates to a peculiar Caribbean context where history has either been completely lost, or never objectively recorded. Accordingly, Cliff calls for a special role to be ascribed to fiction, imagination and unrecorded memory in order to reconstruct an endangered Afro-Caribbean past. Thus, "fiction" and "historical imaginations" stand as reliable means for retrieving what has been lost and/or misrepresented in Eurocentric texts about the Caribbean. Critic J. Michael Dash underlines the value of "creative imagination" in the wider Postcolonial Caribbean project of historical re-inscription and identity reconstruction: "In a situation where the group is ignorant of its past, resentful of its present impotence, yet fearful of future change, the creative imagination has a special role to play. Martinicans need writers to tell them who they are" (1989, p. xix).

It is also important to note that Cliff heavily relies on real events from Caribbean history to create her stories, settings, characters and symbols. In Abeng, for instance, Cliff puts fictional events alongside factual testimonies and details from real Caribbean history. Quite curiously, Cliff's narrator freely oscillates between recounting the fictional life of Clare Savage, the protagonist in Abeng and No Telephone to Heaven, and narrating the historical 'discovery' of the Caribbean world by Christopher Columbus in 1494. The following extract is worth examining in this respect:

Christopher Columbus discovered-strange verb-Jamaica in 1494, while on his second journey across the curve of the globe for Isabella and Ferdinand. [...] The series of his voyages began in 1492, the year he sighted Cuba and made a landfall on the island which became known as Hispaniola. [...] The name of the Carib in their own language was Galibi. Carib was invented by Columbus, and was later changed to Canibal--the origin of the English word cannibal--because it was said that the Galibi ate human flesh. The men of the Galibi spoke their own language; the women spoke only Arawak. They were a fierce warrior people who opposed the conquistadores with skill and power. [...] They were all but exterminated by the Spanish conquerors. But they exist not only in the past--there are a few who survive today on a reserve on the island of Dominica. (Abeng, pp. 66-67)

Though fictional, the above passage can easily qualify as a piece of historical writing. The precise dates ("1492" and "1494"), the real names ("Columbus") and places ("Cuba," "Jamaica" and "Hispaniola") and the actual events from Caribbean history prove the history-bound nature of Cliff's fictional text. Worthy of note is the way the narrator easily shifts from recounting Clare's fictional life to the very moment that brought the "Galibi" and "Arawak" face to face with imperial Europe when "Columbus discovered Jamaica in 1494."

Cliff's narrator does not simply recount historical facts, but also engages in a process of historical revision and interrogation. The narrator's reaction to the verb "discovered" is interesting in this respect; this verb is considered "strange" because it distorts an essential truth about Caribbean history. The verb "discovered" implies that the Caribbean world started to exist only when the Europeans first set foot on its soil, hence to normalness of its appropriation and occupation as an empty and unclaimed space. "Their so-called discoveries reek of untruth," Cliff tells us in The Land of Look Behind (1985, p. 66) denouncing the fraudulent nature of the word "discovered" which deliberately outlaws Caribbean pre-colonial history and erases the culture that predated the arrival of the Spanish conquistadors into the region.

The other historical fallacy Cliff dismantles in Abeng is the myth of the cannibal Caribbean native: "it was said that the Galibi ate human flesh" (p. 67). Reacting to this stigmatization, Cliff's narrator travels back in time to the origin of things tracing the roots of such words as "Carib," "Galibi," "Canibal" and "cannibal". The excavation of the etymology of these 'labels' proves that a great deal of Eurocentric history about the Caribbean is based on unfounded distortions, fantasises and blunt lies. Indeed, much of Columbus's portrayal of the Caribbean was determined by the "carved" "fantasies" "Christian European imagination" had about "imagined inhabitants" and "bizarre" worlds abroad (Abeng, p. 79). It is, thus, Europe's "heart of darkness" which imagined the Caribbean natives as "less than human" (Abeng, 
p.79). Even more strangely, Caribbean natives were mis/represented to the uninformed and inexperienced European in these frighteningly "bizarre" manners: "Dog-headed beings with human torsos," "Winged people who could not fly," "Beings with one foot growing out of the tops of their heads," and "People who ate human flesh. All monsters. All inhuman" (Abeng, p. 78).

These stigmatizing "fantasies" about the Caribbean can be read as part of wider distortions and fallacies upon which the European imperial project was founded. Indeed, the bestializing of the non-European other was an ideological 'tyranny' propagated by the propagandists of European Empires to legitimize the conquest of other nations and territories. Exploring the ideological premises and untruths that underlie Europe's misrepresentation of its nonEuropean Other, Brydon and Tiffin talk about the "journals of explorers, imaginative accounts by medieval travellers who never left home" and how:

the subsequent histories of exploration and conquest facilitated the 'othering' of the rest of the world, and the bolstering of Europe's idea of itself as the centre of civilization, one morally and materially superior to all others, and having the 'divine' right or religious duty to convert and destroy. (Decolonizing Fiction, 1993, p. 42)

\section{Clare Savage: The 'Thirst' for Stories}

Throughout Abeng and No Telephone to Heaven, Clare Savage, the central character in both novels, is irresistibly eager to know the lost history of her Afro-Caribbean ancestors, a history distinct from the 'tamed' version imparted to her by her racist father and white-centered education in colonial Jamaica. Clare is thus deeply anxious that her "island did not know its own history" (Abeng, p. 96), a history she judges as "lost in romance" (p. 30). Clare's awareness about the loss of her ancestral memory shows the strong need she feels, as colonial subject and slave descendent, for communal and self-knowledge. After many years of wandering across Europe and America, Clare returns to the island of her birth (i.e. Jamaica) deeply convinced that she "could live no longer in borrowed countries" (No Telephone to Heaven, p. 193). She thus undertakes the study of her Afro-Caribbean history, a history she could not regain in the "borrowed countries" she lived in for many years. The following passage further addresses my point:

I have educated myself since my return. Spoken with the old people...leafed through the archives downtown ....spent time at the university library... one thing leads to another. I have studied the conch knife excavated at the Arawak site in White Marl...the shards of hand-thrown pots...the petroglyphs hidden in the bush...listened to the stories about Nanny and taken them to heart. I have seen the flock of white birds fly out at sunset from Nanny-town...duppies, the old people say. [...] Ghosts; the spirits of Maroons [...] I have walked the cane...poked through the ruins [...]. I have swum underwater off the cays. History can be found underwater. Yes--some history is only under water. (No Telephone to Heaven, p. 193)

Clare's endeavours to retrieve her ancestors' unacknowledged history are reflected by the special diction used in the passage. The words "educated," "leafed," "archives," "university," "library," "studied," "listened," "stories," "excavated" and "history" are extremely telling about Clare's hunger, so to speak, for her community's concealed hi/stories. This extract is an illustration of Clare's journey back to her roots to rediscover submerged memories reaching back to the time of slavery. The opening sentence ("I have educated myself since my return") suggests the beginning of a reconstruction process through which Clare hopes to regain forgotten aspects of her people's past. The hidden nature of this past can be guessed from the reiteration of the word "underwater," tellingly used thrice in the passage. The prefix "under" signals the amount of excavation that needs to be done to uncover slavery's untold secrets.

From another angle, the sentence "History can be found underwater" clearly rings a bell about the hidden horrors of the Middle Passage. The way this horrendous cross-Atlantic transit happened and the way slaves faced this plight while on board slave ships remain unknown, except for the sea under whose recesses millions of slaves were thrown dead and alive. The sea represents an interesting site of memory since it witnessed the exact unfolding of the Middle Passage. The concealed horrors of the Middle Passage are further dwelt upon in Abeng. The narrator evokes the memory of those who "died onboard and their bodies were dropped in the sea along the Middle Passage" (p. 7). Foregrounding the destructiveness of this passage and its burdensome lingering memory, Clare hurtfully wonders whether God was not shaken by the inflictions of this existential predicament: "Was the god not damaged by the passage? Was he not born again?" (p. 177). Clare's rhetorical question about whether God was "not damaged" by what slaves suffered during the Middle Passage invites us to imagine the untold depredations slaves underwent at the hands of their enslavers during the infernal journeys to the Americas.

As a matter of fact, the largest part of Clare's digging and self-education into her community's historical and cultural memory relies on the oral "stories" "old people" preserve and pass on from one generation to another. Bearing in mind its value as a "central metaphor for the ability to communicate" "history through the generations" (Davies and Fido, 1990, p. 6), oral storytelling permits the upholding of unrecorded memory and 'hushed' testimonies. Quite significantly, the phrases "Spoken with the old people," "listened to the stories," and "the old people say" (No Telephone to Heaven, p. 193) show how Clare heavily relies on her community's oral tradition to retrieve the endangered hi/stories of slavery. Addressing the value of oral storytelling in Cliff's texts in general, Agosto proposes that Cliff "broadens the use of oral history" and "traditional knowledge," both as a "weapon against extinction" and a "means to preserve the African heritage" (1999, pp. 42, 78). 
Cliff's re-centering of the submerged history of slavery is also indicated by Clare's fluid vacillation between her present and her ancestors' centuries-old slavery memory. Quite often, Cliff's narrator leaves off recounting Clare's complex life story, and returns to what started it all; when Europeans forcibly "brought people here in chains and then expected to prosper" (Abeng, pp. 164-165). Despite its remarkable briefness, this statement is rich in historical allusions as it addresses the strictly hierarchical subject positions of slaves and masters. The dichotomous identities of slaves and masters are pointed by the terms "chains" and "prosper," respectively: the former tells about slaves' loss of agency and animal-like status, while the latter points to the enslavers' unquenchable thirst for profit and stark commercialization of slaves. "The commodification and transportation of human flesh across the Atlantic Ocean," Brown-Hinds suggests, "produced generations of 'humanless' humans in which every bodily action had economic consequences" (1998, p.108).

Slaves were reified both by the custodians of the plantation economy and the discursive and ideological formations that sustained Europe's handling of its enterprise. The dehumanization of the slave figure was, in fact, at the heart of Europe's wider imperialist project implemented through slavery and colonialism. Indeed, slavery was a ruthless lucrative system that sought to exploit land and people in very profound ways. Founded on the assumption that a slave was a mere object of trade, slavery was blindly profit-centered and slaves' bodies were openly reified.

Though removed from the dreadful unfolding of slavery by entire centuries, Clare wholeheartedly feels the very bitterness arising from this tragic history:

The enslavement of her Black people--African peoples--with its processions of naked and chained human beings, whipping of human beings, rape of human beings, lynching of human beings, buying and selling of human beings--made other forms of employment in the upkeep of western civilization seem pale. (Abeng, p. 28)

One should not overlook the use of the word "human," tellingly reiterated five times in the above quotation. This remarkable recurrence echoes Clare's insistence that the slaves' humanness be fully recognized despite their deliberate reification in imperial discourse and the everyday realities of the slavery. Indeed, Imperialism regarded Africans as primitive people with limited mental capacities, little or no historical achievements and inferior cultural traditions. From the time of slavery onwards, Walcott argues, the Caribbean has been conceived as an "illegitimate, rootless, [and] mongrelized" world: "No people" or, at best, "[f]ragments and echoes of real people, unoriginal and broken" (The Antilles: Fragments of Epic Memory, 1993). Ngugi Wa Thiong'O speaks about the deformation of the African's human identity by the "geniuses" of Western "racism" and the "giants of western intellectual and political" imperialism (Decolonizing the Mind, 1986, p. 18)

Clare's problematic identity is clearly connected to her slave ancestors' tragic memory of "whipping," "rape," "lynching," "buying" and "selling" (Abeng 28). Thus, Clare's troubled present had been dictated centuries earlier by the irreparable history of slavery that lingers on through its haunting memories. The horrendous history of slavery, now memories to Clare, did not affect slaves only, but turned into trauma for their descendents in the present day Caribbean. Slavery is over, yet its indelible psychic wounds still 'hang around' in the hearts and minds of those historically connected to it. In her article "History as Fiction, Fiction as History", Cliff addresses the persistence of slavery memory and its impingement upon of black Jamaicans: "The past coexists with the present in this amnesiac country in this forgetful century. It is as Toni Morrison says in Beloved: 'Everything is now. It is all now'” (1994, p. 198). Clare's strong affiliation with her ancestors' remote slavery past can be also investigated through this passage from No Telephone to Heaven:

I am in it [i.e., the history of slavery]. It involves me...the practice of rubbing lime and slat in the backs of whipped slaves...the ambush tactics of Cudjoe...the promised flight of Alexander Bedward in rapture back to Africa... cruelty...resistance....grace. I'm not outside this history--it's a matter of recognition....memory...emotion. (p. 194)

Despite her temporal removal from the slavery past by entire centuries, Clare cannot resist her wholehearted affiliation with this ancestral past. Clare's use of the simple present tense ("I am," "involves," "I'm," and "it's") when evoking the remote past of slavery asserts its strong persistence through the power of "recognition," "memory" and "emotion." Despite her historical distance from the tragic experience of slavery, Clare insists that she is "in it" and that it "involves" her emotionally and mentally. Clare's whole-hearted attachment to her people's history (unfolding centuries before she was born) proves the tenaciousness of slavery memory and the way its lasting psychological legacy cannot be overcome by generations of slave descendents in the contemporary Caribbean and wider black Diaspora.

\section{Conclusion}

In this paper, I mainly examined Michelle Cliff's subterranean consciousness about the immense distortions marring Caribbean history and the urgent need to challenge these distortions by re-writing alternative objective versions of the mentioned history. Focusing on Cliff's historical agenda in a selection of her fictional and non-fictional writings, I particularly looked into how Cliff, as a Postcolonial Jamaican writer, energetically strives to re-write/right erased aspects of her black community's history, mainly that relating to slavery and colonialism. In the case of Cliff, the retrieval of lost testimonies and the granting of voice to historically-silenced men and women are carried out through imagination, fiction, oral storytelling and the revitalization of black people's unrecorded collective memory. These interrelated means of historical re-inscription make possible the re-writing of an alternative Caribbean history that departs from the Eurocentric "official version" that sought to write black history in the Caribbean according to the needs and desires of Europe's Imperial machine. 
Cliff's reconstruction of her people's slavery past is part of a wider Postcolonial project of historical revision and identity reconstruction. Central to this project is writing back to the Eurocentric stigmatizations of native identities, histories and cultures. By excavating Afro-Caribbean unrecorded memory and showing its infinite potential for regeneration, Cliff partakes of her community's historical awakening and cultural re-inscription. Cliff does not simply limit her role to the diagnosis of the colonialist misrepresentations of her communal and ancestral history, but proposes a new version of what has been silenced and/or distorted. As the experience of Cliff's protagonist Clare Savage clearly shows, the retrieval of lost memory and distorted history is a prerequisite for both self-understanding and identity reconstruction as well as resisting the flagrant lies and fallacies that 'tinted' Afro-Caribbean history and culture and for entire centuries.

Acknowledgment: The writer expresses his deepest thanks and gratitude to The Deanship of Scientific Research and The Research Centre at the College of Arts (King Saud University) for funding this paper.

\section{References}

Agosto, N. (1999). Michelle Cliff's Novels: Piecing the Tapestry of Memory and History. New York: Peter Lang Publishing Inc.

Brown-Hinds, P. D. (1998). Long Memoried Women: Memory and Migration in $20^{\text {th }}$ Century Black Women's Narrative. Diss. U of California.

Brydon, D. and Tiffin, H. (1993). Decolonizing Fiction. Sydney: Dangaroo Press.

Cliff, M. (1980). Claiming an Identity They Taught Me to Despise. Watertown: Persephone Press.

Cliff, M. (1984). Abeng. New York: Penguin Books.

Cliff, M. (1985). The Land of Look Behind: Prose and Poetry. New York: Firebrand Books.

Cliff, M. (1987). No Telephone to Heaven. New York: Plume.

Cliff, M. (1994). “History as Fiction, Fiction as History.” Ploughshares, 20(2-3), 196-203.

Cliff, M. (1994). "Journey into Speech: A Writer Between Two Worlds": An Interview with Opal Palmer Adisa. African American Review, 28(2), 273-281.

Cliff, M. (1994). Free Enterprise. New York: A Dutton Book.

Dash, J.M. (1989). “Introduction.” In Glissant, E. Caribbean Discourse (Trans. J. Michael Dash). Charlottesville: U P of Virginia, xi-xlv.

Davies, C. B. and Fido, E.S. (Eds.) (1990). Out of the Kumbla: Caribbean Women and Literature. Trenton: Africa World Press.

Ngugi, W. T. O. (1986). Decolonizing The Mind. London: James Currey.

Phillips, C. (2002). A New World Order. London: Vintage, 2002.

Rody, C. (2001). The Daughter's Return: African-American and Caribbean Women's Fictions of History. New York: Oxford University Press.

Sarvan, C. and Marhama, H. (1991). "The Fictional Works of Caryl Phillips: An Introduction." World Literature Today, 65(1), 35-40.

Shea, R. H. (1994). "Michelle Cliff.” Belles Lettres: A Review of Books by Women, 9(3), 32-35.

Walcott, D. (1993). The Antilles: Fragments of Epic Memory (The Nobel Lecture). New York: Farrar, Straus and Giroux. 